\title{
Luxación crónica recidivante. Tratamiento del componente óseo y muscular: osteotomía glenotemporal de Norman
}

\author{
Chronic recurring dislocation. Treatment of muscular and bone components: Norman glenotemporal osteotomy
}

Se han descrito diversos tratamientos de la luxación recidivante de la articulación témporomandibular. Éstos incluyen medidas no quirúrgicas: fisioterapia, férulas oclusales, modificación conductual, fármacos anticonvulsivantes o relajantes musculares; técnicas mínimamente invasivas: infiltración de sustancias esclerosantes intra o periarticulares, infiltración de toxina botulínica en músculos de la masticación o la inyección se sangre autóloga intraarticular. También se han publicado numerosas técnicas quirúrgicas que tratan los diferentes componentes articulares: aumento o eliminación de la eminencia articular, refuerzo de la cápsula articular y sus ligamentos, eliminación de la tracción muscular del músculo pterigoideo lateral.

La existencia de todos estos procedimientos reflejan la posible etiopatogenia multifactorial de la luxación recidivante: laxitud de la cápsula y los ligamentos, hipertonía muscular, alteraciones en la anatomía ósea normal de la articulación o existencia de trastornos internos articulares asociados (desplazamiento anterior del disco, sinovitis, osteoartrosis).

La mayoría de las publicaciones existentes (como la del presente artículo) presentan estudios clínicos que evaluan la eficacia de una técnica en el tratamiento de esta entidad. No existen estudios prospectivos randomizados que comparen unas técnicas con otras. $Y$ por otra parte en la mayoría de ellos tampoco están convenientemente descritas la patología articular que se trata, ni presentan resultados a largo plazo. De la revisión bibliográfica puede inferirse que cualquier técnica (desde las más compleja a la menos invasiva) es adecuada para tratar esta patología. Probablemente esta conclusión no sea correcta.

El diagnóstico de la causa o causas de la luxación recidivante es el que nos debe guiar en la selección de la mejor modalidad de tratamiento del paciente. La historia clínica (edad del paciente, existencia de patología ligamentosa sistémica, trastornos neurológicos o musculares), la exploración (hiperlaxitud articular, bloqueo en boca abierta, ruidos articulares) y la RM (trastorno internos asociados, morfología ósea articular) nos permitirán evaluar qué componentes de la ATM y de los músculos de la masticación deben ser tratados.

Los autores del presente artículo no presentan los resultados de la RM que realizan en el preoperatorio por lo que no podemos saber en que casos existían trastornos internos asociados. Sólo realizan una meniscopexia y una meniscectomía en su serie (¿en el resto de los casos los discos estaban situados en una posición normal?). No queda definido ni en material y métodos ni en los resultados como han evaluado las variables clínicas (dolor, ruidos, apertura
Many treatments for recurring dislocation of the temporal mandible joint have been discussed. They include non surgical methods such as physiotherapy, occlusal splints, behavior modification, non convulsive medications or muscle relaxers; minimally invasive techniques: infiltration of intra or periarticular sclerosing substances, infiltration of toxins in the chewing muscles or injection of autologous intra articular blood. Many surgical techniques have also been published that deal with different articular components: increase or elimination of the articular eminence, reinforcement of the articular capsule and its ligaments, and elimination of the muscular traction of the lateral pterygoid muscles.

The existence of all of these procedures reflects the possible multifactor etiopathology of chronic dislocation: Looseness of the capsule and the ligaments, muscular stiffness, changes in the normal bone anatomy of the joint, or the presence of internal associated joint disorders (anterior disc shift, synovitis, bone arthrosis).

The majority of existing publications (like this article) discuss clinical studies that evaluate the efficiency of a treatment technique of this type. There are no prospective randomized studies that compare one technique to another. The majority of the ones that exist don't explain the articular pathology that treat, nor do they provide long term results. Reviewing the biography one could conclude that any of the techniques is adequate to treat this pathology. This conclusion probably isn't true.

Diagnosis of the cause or causes of recurring dislocation is what should guide us in our choice as to how to best treat the patient. Medical history (patient age, presence of ligament system pathology, neurological or muscular disorder), investigation (very loose joint, blocked mouth opening, joint noise), and an MRI (internal associated disorders, joint bone morphology) will allow us to evaluate which components of the TMJ and the chewing muscles should be treated.

The authors of this article do not show the results of the MRI taken before operating; because of this we don't know which cases had associated internal disorders. They only performed a meniscectomy and a meniscopexy in their series (in the rest of the cases were the discs situated normally?). There is no mention, in the materials and methods section or the results section, of how the clinical variables were measured (pain, noise, oral opening etc.) which makes it difficult to evaluate the results. The two patient groups with the high- 


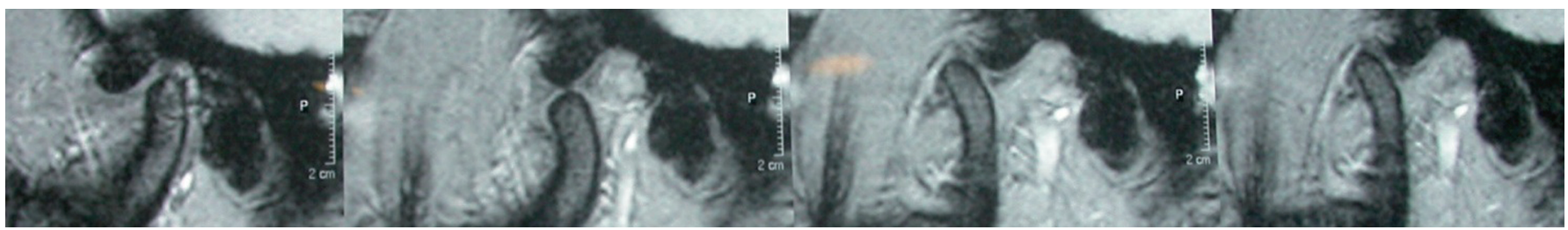

Figura 1. RM: luxación recidivante en paciente con disco en posición normal. Hiperlaxitud articular y eminencia normal.

Figure 1. MR: Recurring dislocation in a patient with a normally positioned disc. Hyper looseness and normal eminence.

oral, etc.) por lo que resulta difícil evaluar sus resultados.

Los dos grupos de pacientes con luxación recidivante que encontramos con mayor frecuencia en nuestras consultas son: pacientes ancianos con trastornos neuropsiquiátricos (demencias, espasticidad) y pacientes a menudo mujeres jóvenes con hipermovilidad articular.

Cuando han fracasado las medidas conservadoras (control de espasticidad, movimientos oromasticatorios anormales, ejercicios isométricos de musculatura de cierre oral, infiltración con toxina botulínica en casos seleccionados) quizás el tratamiento quirúrgico de primera elección en el primer grupo de pacientes sea la eminectomía (Myrhaug $\mathrm{H}, 1951$ ) bilateral. Este procedimiento extraarticular nos asegura que el paciente no va a volver a presentar episodios de luxación de una forma sencilla, predecible y con una rápida recuperación.

La selección de la técnica quirúrgica en el segundo grupo de pacientes dependerá del diagnóstico etiopatogénico y de la coexistencia de trastornos internos articulares secundarios. En los casos de hipermovilidad articular por laxitud con una eminencia de altura normal (Fig. 1) quizás el procedimiento de elección sea la artroscopia (al ser una técnica menos invasiva que la artrotomía) (Merrill RG, 1992; Onishi M, 1989; Fernández Sanromán J, 2009). Mediante control artroscópico se puede retensar la cápsula articular mediante dis-

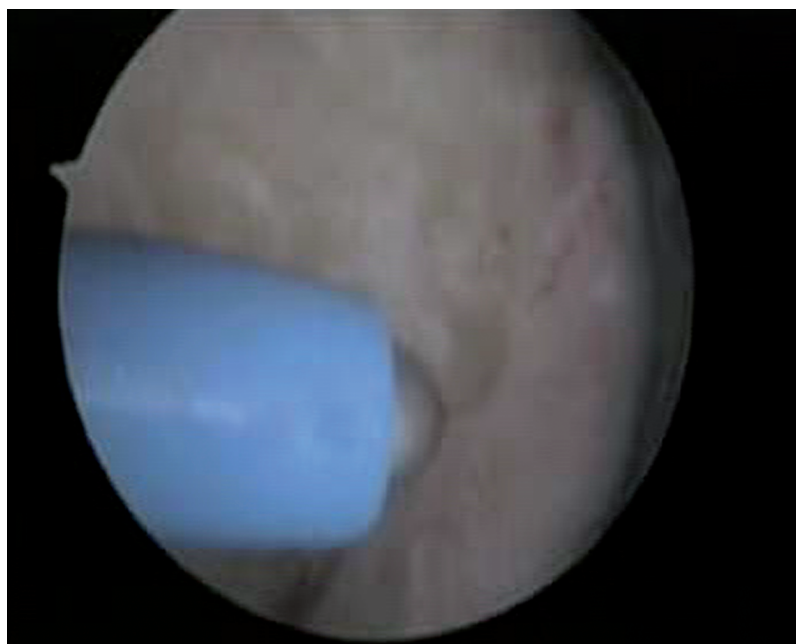

Figura 2. Retensado cápsula lateral y ligamento retrodiscal ATM derecha mediante terminal de radiofrecuencia.

Figure 2. Tightened lateral capsule and retro disc ligament of right TMJ using radiofrequency terminal.

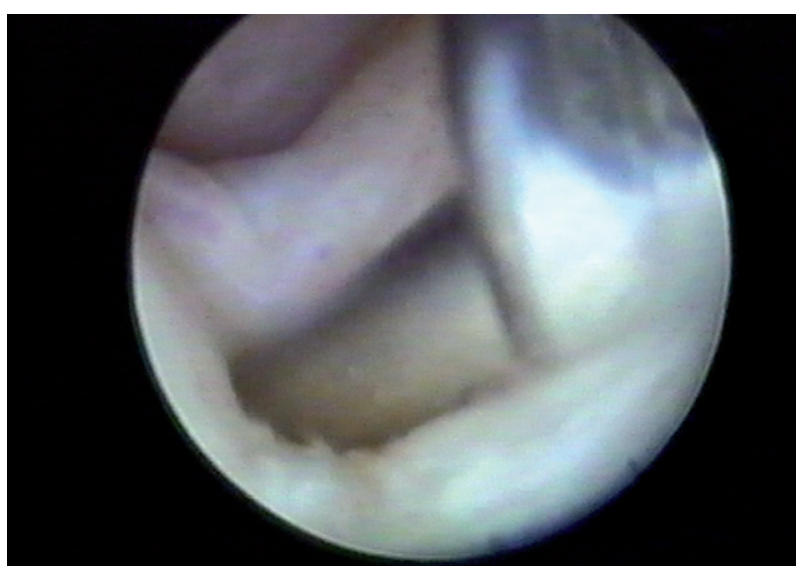

Figura 3. Infiltración ligamento retrodiscal bajo control artroscópico con sotradecol.

Figure 3. Lateral pterygoid muscle infiltration controlled under arthroscopic control with sotradecol. est frequency of recurring dislocation are older patients with neuropsychological disorders (dementia, spasticity) and young women with joint hyper mobility.

When conservative methods failed (control of spasticity, abnormal chewing movements, isometric oral closing exercises, infiltration of botulin toxin in select cases) perhaps the most commonly chosen surgical treatment in the first group of patients is bilateral eminectomy (Myrhaug $\mathrm{H}$, 1951). This extra articular procedure ensures that the patient will not have more dislocation episodes; it is simple, predictable and has a fast recovery time.

Selecting a surgical technique for the second group of patients will depend on the etiopathogenic diagnosis and the coexistence of secondary internal joint disorders. In cases of joint hyper mobility caused by looseness with the eminence at a normal height (Fig. 1) perhaps the best procedure would be arthroscopy( being that it is a less invasive than arthrotomy) (Merrill RG, 1992; Onishi M, 1989; Fernandez Samromán J, 2009) Several things can take place using arthroscoppositivos de radiofrecuencia (Fig. 2), realizar infiltración de sustancias esclerosantes en el ligamento posterior o la cápsula articular (Fig. 3), tratar los trastorno internos mediante técnicas de reposición discal y disminuir la tracción del músculo pterigoideo lateral bien mediante miotomía (Fig. 4) o por infiltración directa con toxina botulínica (Fig. 5).

En los casos excepcionales en los que exista una disminución de la altura de la eminencia se puede plantear o bien la eminectomía ic control: the articular capsule can be retightened using radiofrequency devices (Fig. 2), infiltration of sclerosing substances in the posterior ligament or articular capsule (Fig. 3), treatment of internal disorders by repositioning the disc and reducing the traction of the lateral pterygoid muscle (Fig. 4), or by directly infiltrating with botulinum toxin (Fig. 5). 
(que altera la mecánica normal de la articulación con riesgo en el futuro de trastornos internos) o cualquier técnica de aumento de la altura de la eminencia asociada o no a la reposición del disco articular si éste está desplazado anteriormente. La técnica de Norman con interposición de calota craneal como describimos en 1997 (Fernández Sanromán J, 1997) nos parece una alternativa más segura y predecible que la colocación de materiales de osteosíntesis que pueden producir problemas en el futuro al estar sometidos a cargas constantes en pacientes jóvenes.

\section{Jacinto Fernández Sanromán} Jefe de Servicio.

Servicio Cirugía Oral y Maxilofacial Hospital POVISA, Vigo, España

\section{Bibliografía}

1. Myrhaug H. A new method of operation for habitual dislocation of the mandible: A review of former methods of treatments. Acta Odontol Scand 1951;9:247.

2. Merrill RG. Mandibular dislocation, in Keith DA (ed): Surgery of the temporomandibular joint. Cambridge, MA, Blackwell Scientific 1992;170.

3. Onishi M. Arthroscopic surgery for hypermobility and recurrent mandibular dislocation. Oral Maxillofac Surg Clin North Am 1989;1:15364.

4. Fernández Sanromán J. Atlas de artroscopia de la ATM. Madrid, Ripano (En prensa).

4. Fernández Sanromán J. Surgical treatment of recurrent mandibular dislocation by augmentation of the articular eminence with cranial bone. J Oral Maxillofac Surg 1997;55:333-8.

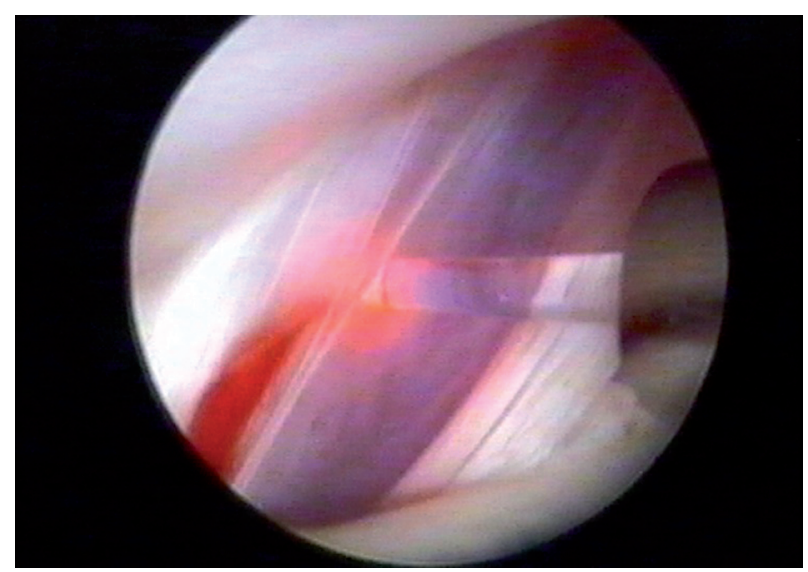

Figura 4. Miotomía del músculo pterigoideo lateral mediante laser Nd-Yag.

Figure 4. Mytomy of lateral pterygoid muscle using an Nd-Yag laser

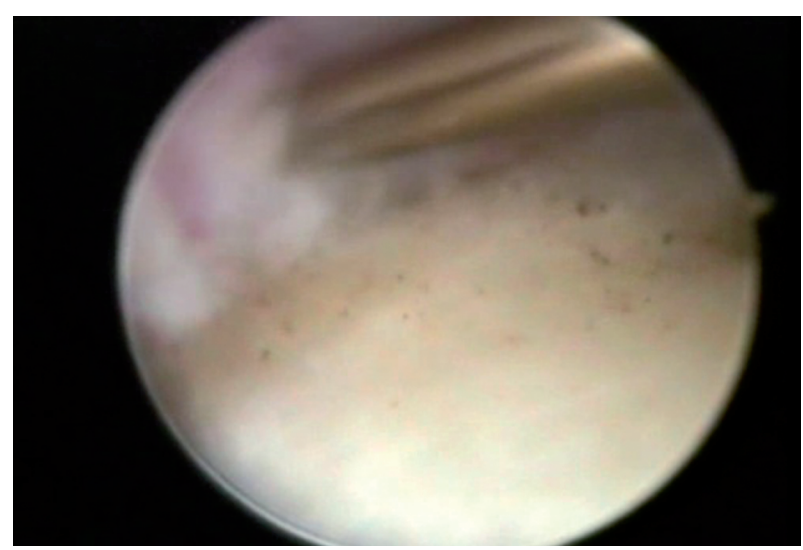

Figura 5. Infiltración del músculo pterigoideo lateral bajo control artroscópico con toxina botulínica.

Figure 5. Lateral pterygoid muscle infiltration controlled under arthroscopic control with Botulinum toxin.
In exceptional cases where there is reduced height we can use either eminectomy (which alters the normal mechanics of the joint risking future internal disorders) or any technique that increases the height of the eminence or not repositioning the articular disc if it is previously displaced. The Norman technique with intervention of the cranial calvarium like the one described in 1997 (Fernandez Sanromán J, 1997) seems to be the more certain and predictable than collocation of bone synthetic materials that could cause future problems because of being subjected to constant load in young patients. 